\title{
Challenges in Ascertaining ICT Skills Requirements in South Africa
}

\author{
H H Lotriet ${ }^{1}$, M C Matthee, P M Alexander \\ University of Pretoria, Lynnwood Rd, Hatfield, Pretoria
}

\begin{abstract}
World wide, a number of far-reaching decisions regarding ways to address the ICT skills shortage are made by both the public and private sectors. These are based on information obtained from various sources and in various ways including quantitative research reports commissioned by government authorities. This paper reports on findings of a systematic textual examination of existing ICT skills shortage research reports with the South African reports receiving particular attention. This analysis shows that the collection of accurate data on ICT skills availability is extremely difficult, if not impossible, as the skills categories used in a diverse, ever-changing ICT environment are ill-defined, the data collection procedures are flawed and the results are difficult to interpret. In addition, successive reports frequently note the weaknesses of the data, but then use it as the basis for their findings. A recommendation from this research is that a Research Methodologies group be formed specifically to discuss this and with the brief to suggest some guidelines and to monitor and endorse future data collection and analysis.
\end{abstract}

\section{CATEGORIES AND SUBJECT DESCRIPTORS}

K.7 The Computing Profession

GENERAL TERMS

Management

KEYWORDS

e-Skills, ICT skills shortage, research methodologies

\section{PROBLEM STATEMENT}

There is a general sense that South Africa is experiencing an Information and Communications Technology (ICT) skills shortage. However, establishing the extent of the shortage and the nature of skills needed is difficult. There are, as is illustrated below, conflicting reports on numbers. There seems to be a need by employers for graduates but there are reports of ICT graduates without jobs. This paper looks at the reasons for this confusion. It seems as though decisions to start new institutions are being made based on perceptions regarding the extent and scope of the perceived ICT skills shortage and that these perceptions are on occasion proving to have been too hastily formed. This paper investigates the research methodology underlying the collection of that data and the analysis used in reports upon which decisions are based. It is important to note that for the purpose of this paper the term 'ICT skills' is considered to comprise a sub-set of skills of the wider term eSkills.

\footnotetext{
${ }^{1}$ E-Mail: (Hugo.Lotriet)(Mactheld.Mathee)(Patricia.alexander)@up.ac.za
} 
The actual research being evaluated within this paper does not cover the full spectrum of e-Skills ${ }^{2}$ as the research that is being evaluated does not look at the skills that the ordinary citizen needs in order to participate fully in the information society. Instead it focuses only on higher level ICT skills, i.e. the skills needed by ICT professionals in order to contribute productively to the ICT sector.

This paper is structured as follows: (1) For the purpose of providing the reader with some background, a short discussion is provided on some current initiatives to alleviate ICT skills in South Africa; (2) A summary of existing research on ICT skills shortages is provided as a context to our own critical discussion of this phenomenon; (3) Challenges in the research of this phenomenon in South Africa are identified; and (4) Some concluding remarks and recommendations are made.

\section{NEWS REPORTS AS BACKGROUND}

News reports in 2008 and 2009 give estimates of both supply and demand with respect to the ICT skills shortage. For example, a report on vacancies for university and university of technology graduates in South Africa, undertaken by a specialist student and graduate research company, stated that the demand had remained fairly stable despite the economic downturn,

"There were about 4000 vacancies for university and university of technology graduates in the 77 South African firms that took part in the 2009 graduate recruitment survey conducted ..." [3]

It is important to note that this quoted report does not refer to ICT graduates (i.e. persons who have specialized in information or communications technology), but graduates from all disciplines. The report gives no indication of the number of ICT graduates required for all companies in South Africa. It is only possible to deduce from this report that the requirements for qualified people were fairly stable up to the time of the survey.

There is some confusion regarding the issue of demand for specifically ICT skills. Whereas the first National Master Scarce Skills List for SA [4;5] indicated a shortage of nearly 40000 ICT workers, Adrian Schofield, manager of the Applied Research Unit of the Johannesburg Centre for Software Engineering (JCSE) at Wits University was reported as claiming that,

“... last year's survey suggested the 'real' skills shortage going into 2009 could be as high as 70000 practitioners - more than $25 \%$ of the current workforce." [6]

Further confusion arises regarding the issue of unemployed ICT graduates:

2 The definition for e-Skills has been adopted from The European E-Skills Forum report [1] and comprises ICT practitioner skills, ICT user skills and e-Business skills. However, in line with e-Skills UK, the definition is extended to include members of society using technology for private purposes.

"This ranges from the ability of businesses to understand and gain competitive advantage from the exploitation of IT, through to the IT user skills every person needs to participate in the eeconomy." [2]
"At the time of the launch, Mopaki noted that there were 1800 unemployed university graduates registered on Iset [sic] Seta's database, and that the private sector and government needed to work harder in order to fill the skills gap in the market." [7].

Since ISETT SETA is devoted explicitly to the ICT sector, it seems that these graduates are ICT graduates. Some joint initiatives involving learnerships are being undertaken specifically to address this problem [8]. However, it does not seem that these learnerships are being filled by unemployed ICT graduates since the report on the ISETT SETA - Microsoft Student-to-Business initiative indicates that graduates and nongraduates are included in an extended programme [8]. An interview with the senior person involved with the programme revealed that graduates with non-ICT degrees were also recruited since sales and marketing do not need ICT skills per se. Nor is it clear how reliable the ISETT SETA's database is given the fact that the Microsoft Student-to-Business initiative referred to above does not use that database, but instead requires students to register on a portal.

The suggestion now seems to be to legislate in order to 'solve' the problem.

“... Mopaki stated that the Department of Labour will pass a bill in the near future to ensure that all companies register their existing vacancies in the ICT sector, which will enable trained graduates to find employment faster." [7]

Public-private partnerships embarking on initiatives to address the various problems of an ICT skills shortage, skills mismatch and graduates whose skills are not up to standard seem to be having limited success in terms of the number of people they are accommodating and the sustainability of the programmes. For example, ten students were admitted in the Neotel pilot project during 2007 and twenty-seven (out of more than 600 applications) in 2008 [9]. The eSkills Academy (not to be confused with the Meraka e-Skills Institute, but also arising from the Presidential International Advisory Committee on Information Society and Development (PIAC on ISAD)), registered 63 unemployed graduates who started an Oracle Development Programme (EDP) in 2008 but this academy closed at the end of 2008 apparently because they were unable to get sufficient support from industry $[10 ; 11]$.

\section{RESEARCH METHODOLOGY}

In this research, the authors undertook a comprehensive and systematic collection of documents including news reports and formal, usually extensive, official reports. Some of these were publically available and others were obtained by requesting copies of privately commissioned reports. Most of the material refers specifically to South Africa, but international reports were also read and evaluated to provide a means of fair comparison and evaluation. All the material used is listed in the bibliography. Some of the material was confirmed by interviewing stakeholders. A typological analysis was performed in order to create categories of research challenges evident from these reports. The quality of each research project (that is, the research processes, findings and structure) was evaluated in terms of consistency, completeness, rigour and validity and associated challenges were identified. The researchers did not examine the reports with any pre-determined notion of the 
appropriateness of different research methods in examining eskills shortages; instead each report was examined on its own merits.

The primary research question is: What are the methodological issues and challenges associated with the data collection and analysis on which market intelligence on supply and demand of ICT skills in South Africa is based?

The themes emerging around challenges to South African ICT

skills research constitute the findings of this paper.

\section{LITERATURE ON ICT SKILLS SHORTAGES RESEARCH}

\subsection{Addressing root causes of ICT skills shortages in South Africa}

The political leaders and government agencies in South Africa are acutely aware of the need to improve skills throughout all sectors of the economy and the education of South Africans in general and a broad spectrum of ICT skills are seen to be receiving particular attention [4]. These attempts to address root causes have the additional advantage of helping to narrow the digital divide and to give basic e-Skills, (as defined in footnote 1 ), to every school child.

The problems in education are receiving ongoing attention. Strategies over the last fifteen years have included: (1) Replacing the eighteen racially divided education departments by single department (ministry) of education [12]; (2) Allocating an unusually high percentage (in 2008 this was $5.3 \%$ of GDP) of the annual state budget to education [13]; (3) Special support programmes to increase the pass rate in Maths and Science at higher grade (required for entrance to engineering and computer science degree programmes by the majority of universities in South Africa) [14]; (4) New national curricula for various stages and segments of education; (5) Policies and supporting authorities such as National Qualification Frameworks, regulated by the South African Qualifications Authority [15];

These initiatives have in general had limited success and references are made disturbingly often to "the crisis in education" [16]. In fact, the Department of Education was restructured in 2009 with a new department for pre-primary, primary and secondary education and a second department focusing on vocational and tertiary education [17]. A further challenge relates to the introduction of Maths Literacy and Maths in the place of Maths Standard grade and Maths Higher grade at secondary schools. Maths Literacy does not provide potential ICT graduates with adequate mathematical background. However, initiatives to stimulate the ICT sector have not been limited to the education sector. Advisory bodies, such as the Presidential International Advisory Committee on Information Society and Development (PIAC on ISAD) that was established in 2001, have been established and ICT has been explicitly included in several pieces of legislation and policies. Sector Education and Training Authorities (SETAs) were established in March 2000 under the Department of Labour and the ISETT SETA regulates the Information Systems Electronics and Telecommunication Technologies sector.
The potential of the ICT sector to contribute to job creation is a major reason for the attention it is receiving at the highest levels in the South African government namely, PIAC on ISAD, Accelerated and Shared Growth Initiative for South Africa (AsgiSA) and the Joint Initiative on Priority Skills Acquisition (Jipsa established 2006 in the office of the deputy president) [18]. This potential has been reconfirmed in recently commissioned reports for the 2009 - 2013 period [19; 20].

One proposal that has been made and accepted by the PIAC on ISAD and the government is the creation of a higher education institute or university dedicated entirely to ICT education and training $[21 ; 22 ; 23]$. As a result, a thorough investigation was launched by the institute set up to carry out this mandate, the Meraka eSkills Institute, into the most effective and efficient model for this institution. It was decided that it should complement existing institutions, collaborate as far as possible, and concentrate on addressing gaps. This institution has been tasked to go beyond improving ICT skills to be used by ICT professionals and in the business arena, and to look at the full spectrum of skills required by all members of society to ensure that they have access to information and can participate fully in the information society. (I.e. the wider set of skills referred to as e-Skills as explained in Footnote 1).

\subsection{Need for ICT-Skills}

It is generally accepted that there is world-wide shortage of people with the ICT skills necessary to boost the economies of the $21^{\text {st }}$ century, $[1 ; 24 ; 25 ; 26 ; 27]$. e-Skills, as defined earlier, vary from low level, computer literacy skills needed by individual members of society to access services to high level technology skills needed by specialist ICT professionals. A further important group of skills are those required by managers and leaders within non-ICT sectors of the economy that allow them to use ICT effectively and innovatively. The contribution that each of these sets of skills makes to society and to the development of the national economy has been described in a convincing way in numerous research reports [25], policy documents $[1 ; 24 ; 28]$ and research papers [29] and hence will not be elaborated on here. Suffice it to say that the current shortage and predicted worsening of the position is receiving urgent attention from a variety of interested parties, including government agencies, educators and trainers, and employers.

The situation regarding the ICT skills gap is made more complicated as technology evolves at an accelerating pace [30] but this rapid rate of innovation is necessary and desirable if the country is to remain competitive. Hence, in order to stay abreast of new technology, knowledge workers need ongoing training ('re-skilling' and up-grading of skills) [25]. Advanced qualifications and infrastructure are also required in order to stimulate research and innovation [1].

What is more, a continuous reciprocal relationship exists between the following four factors: new and changing technologies; the profile of employment opportunities (jobs) within the ICT sector and in other sectors; the acquisition of necessary skills; and the uptake of technology in the personal lives of the population. Unfortunately, this does not all happen in a neat, synchronized way. The dynamic nature of ICT makes the skills shortage difficult to address as it is never-ending. The expectation gap, that is, the mismatch or perceived lag between 
what is taught and what skills are needed, is in part as a result of this quite complex interaction $[26 ; 31 ; 32 ; 33 ; 34 ; 35]$.

The skills shortage is partially a result of ever increasing demand for knowledge workers, but is exacerbated by decreasing numbers of students enrolling for Computer Science and Information Systems courses at universities and even secondary school $[25 ; 27 ; 29 ; 35 ; 36]$. Fortunately, evidence suggests that the numbers of students enrolling worldwide is now leveling off and, in some cases, is even rising. [37]. The South African situation is similar to the world trends in this regard.

The population of South Africa, with its mix of highly industrialized and technology rich areas and others with minimal access to services and technology; and affluent and impoverished communities, is impacted by the ICT skills shortage in various ways and some members of the South African society benefit in only a limited way from the opportunities that a healthy ICT sector offers. The South African National Master Scarce Skills List, drawn up by the Department of Labour in 2007 [5] and upon which new regulations and policy will rely, identifies the following critical ICT needs:

6675 ICT managers; 3025 call or contact centre managers; 710 ICT trainers; 4320 ICT sales professionals; 5555 ICT business and systems analysts; 35 multimedia specialists and Web developers; 6185 software and applications programmers; 95 database and systems administrators and ICT security specialists; 6050 ICT network and support professionals; 3790 ICT and telecommunications technicians; 1125 ICT sales assistants [22]. (Understanding of the scope and nature of each of these job titles obviously constitutes a challenge in itself.)

Since the full report was not obtainable, the research processes used in reaching these numbers are unknown. However, as will be discussed later, defining these job titles is one of the problems of classifying shortages and without access to the definitions used, the results can be interpreted in various ways. However, a preliminary report, dated August 2007, indicates that the IDC research sponsored by Cisco, and the 2005 survey by ISETT SETA provided the numbers.

In response, the government has launched various initiatives intended to address the problem. However, 'knowing' what the extent and the dimensions of the problem are and understanding what processes are required to address the problem, and whether these have significant impact, presents particular challenges.

\subsection{Categories of skills shortage research}

Published research, specifically related to skills shortages in various disciplines, largely focuses on five issues.

- Reasons and motivations that make students choose a major. This includes theoretical models $[27 ; 29]$.

- Important 'side issues' related to career choice (specifically gender) $[38 ; 39 ; 40 ; 41]$ ?

- Curricula, work readiness, relevance and responsiveness to the real world and its fast changing needs $[26 ; 31 ; 33 ; 36]$

- $\quad$ Effective teaching $[27 ; 35]$

- Commissioned large surveys - skills shortages, gaps, current job profiles, job occupancy and vacancies, numbers of enrollments and graduations. Examples are those commissioned by the Australian Government (resulting in the "Building Australian ICT skills" report published in
2006) [24], a series for the e-skills council UK (in particular the "Technology Counts: IT \& telecoms insights", published in 2008) [25] and The European eSkills Forum synthesis report, "E-Skills for Europe: towards 2010 and beyond" [1].

This paper discusses the last of these categories and particularly the various reports produced in South Africa that have been based on big surveys. It examines the methods used for collecting the information used for reaching recommendations and identifies challenges in obtaining the information. Hence the paper does not analyze the recommendations made in the reports, but rather the methods used to collect the data on which these recommendations are based.

\subsection{Reviews of surveys other than the South African reports}

South Africa is by no means alone in carrying out research projects on ICT skills shortages and many of the reasons for this are similar across the different countries (excluding the particular shortage of learners who qualify for admission to university degree programmes that are ICT related). As noted above, research reports have underpinned the creation of councils and institutions devoted to addressing the problem of ICT skills shortages in many countries. Notes concerning research methodology in three international reports follow. These reports are freely available on the Internet. Commercial reports such as WITSA reports (i.e. obtainable at a cost to the user) are excluded from this discussion.

4.4.1 Australian Government, Department of Communications, Information Technology and the Arts 2006. Building Australian ICT skills

This report was compiled by the ICT Skills Foresighting Working Group, convened in 2005 by the Australian Minister for Communications, Information Technology and the Arts in order to study current and future trends in ICT and the implications for e-skills development.

The report concludes that difficulties in the collection of detailed, reliable data (market intelligence) make it difficult to predict future demand. This is partly because inconsistent classification systems are being used. Easy to use, on-line data collection systems together with job recruitment data are suggested as necessary to improve the position. In addition, they suggest that the new Australian and New Zealand Classification of Occupations classification should be used. The group notes that they did not attempt to study the broader basic ICT skill levels required in the Australian community [24: 14]

In addition, the report points out the enormous difficulty and high cost of providing "reliable, quantitative, forecasting of skills demand and workforce numbers" in this particular sector [24: 46-48].

\subsection{2 e-Skills Industry Leadership Board 2008. Policy}

\section{declaration 2008: e-Skills competences}

This policy declaration was submitted to the European Council of Ministers in Brussels in 2008 by the e-Skills Industry Leadership Board that was founded in 2007 under the auspices of the EU with the intention of providing leadership in the 
establishment of a long-term e-Skills development agenda for Europe.

This report notes a need for common, sector-wide terminology for describing ICT professional disciplines [42: 3], together with more detailed specifications in order to make it easier for employers to assess both ICT competencies and transferable business and personal competencies. There is a complementary need to establish a simply way of describing courses offered to improve the availability, accessibility and uptake of training by ICT professionals. The competency model is employer-led. The need for common classification and terminology is a theme which also affects the collection of reliable research data and market intelligence.

\subsubsection{The European e-skills forum 2004 Synthesis Report - e- Skills for Europe}

The European Commission established the European e-Skills Forum in 2003 with the express purpose to enable open discourse by all interested parties on e-skills gaps. This report represents a collation of individual views on e-Skills shortages by members of the Forum.

This report, is a synthesis of information and does not rely heavily on detailed quantitative data [1]. In fact, it proposes that there should be less emphasis on numbers and instead more effort should be put into determining what the relevant skills are [1: 14] and trying to ensure a seamless framework linking various levels of ICT training and education [1: 16]. In support of this idea, this report suggests that, "More qualitative research is also needed to define future skills needs ..." [1: 19]. It agrees with other reports about the inconsistent data available. "Eurostat and national statistical offices should work together to clarify, agree on and implement best practices in classifying and gathering the data needed." [1: 19]

\subsubsection{Concerns regarding e-Skills estimates in Europe}

The e-Skills Monitor project, which involves study teams from two organizations that monitor supply and demand of e-Skills in Europe on behalf of the European commission, lists a number of concerns related to the estimation of e-Skills supply. These include (1) Uncertainty of the impact on supply numbers related to re-skilling of workers; (2) Uncertainty of assumptions related to unemployment numbers, duration of unemployment and workers with e-Skills actually finding work in the ICT sector; (3) Lack of consistent information within different geographic boundaries; (4) Difficulty in recognizing the presence of e-Skills education in qualifications with new and unfamiliar names (labels not normally associated computer science); (5) Uncertainty related to the numbers of skilled persons who are retiring or leaving the sector; (6) The inaccuracies inherited when assumptions for calculations are based on results of previous, non-representative surveys (7) Problems in understanding the impact of economic conditions on assumptions related to supply and demand; (8) Incomplete knowledge about similarities and dissimilarities of e-Skills shortages in large and small organizations [43].

\subsubsection{Other surveys}

A 2009 ICT skills-shortage survey conducted on behalf of the Ministry of Economic Development in New Zealand relied on an online survey instrument amongst 101 companies [44]. The survey is mainly quantitative, with information from a single interview included in the final report. The main drawback with the methodology of the report is the lack of critical discussion of limitations or challenges that allows for critical reflection on the findings.

A World Bank Report on the ICT sector in China implies divergence of definitions of what constitutes a person employed in the ICT industry, the definition thus having an impact on the actual estimate of skills shortages in the sector [45].

\section{FINDINGS}

Many South African ministries (known as Departments in the South African government) are interested in skills development and in ICT skills in particular. It might be for this reason that several reports have been commissioned by different stakeholders in the period since 2000 .

From the reports studied, a number of methodological challenges seem to exist. These are each discussed in this section. For convenience of readers a Table is appended (Appendix A) that summarizes the research approaches as well as main issues related to the various South African reports that were studied.

\subsection{Challenge 1: The worrying absence of various critical} research elements

- Fundamental research to explain and understand the phenomena, on which the existing studies focus, is absent.

- Methods have been largely limited to surveys. Limited evidence exists of other methods such as qualitative methods. In addition, the reports provide limited 'scientific' description of their methods, which makes evaluation of the 'scientific' validity extremely difficult.

\subsection{Challenge 2: Extent of data gathered}

- Who was the data gathered from?

Studies that actually involve subjects other than HR departments and CIO's of large organizations are conspicuous by their absence. It does not seem that the actual practitioners, the placement agencies, the ICT drop-outs, the university lecturers and departments involved in delivering these skilled people have been consulted. Small companies and the informal sector (extremely important in South Africa) are excluded:

"The yellow pages telephone directory was used as a sampling frame to draw the sample for Non-ISETT companies. Since some smaller companies may not have a telephone this may have partly distorted the results. The informal sector has also not been included in the study." [46]

Many of the reports do not list specific sources within organisations where data was gathered or are very vague. One example "based on primary and secondary research including data surveys of CIO-level respondents in South Africa ..." then also refers to $20 \mathrm{CIO}-$ level telephone interviews across large organizations [47]. The topics of the interviews, or whether the telephonic surveys were completed using estimates provided by the CIOs is not clear. The details given in the appendix of this white paper do not assist in this. The report on provision of intermediate skills training by private companies attempted to 
determine future demand based on a literature study, twelve telephone interviews, and analyzing data from one South African web site [48]. These researchers are aware of the limitations of some of their methods and warn that the use of a single careers web site might be misleading and that insufficient data is available from job advertisements as occupational titles are often given without indication of qualifications or experience needed. In this research, a questionnaire was sent via e-mail prior to the interviews to assist the companies to prepare.

- Who gathered the data?

Recognized scientific institutions contribute to the body of knowledge on ICT skills shortages. An excellent research report on the broader, but related, issue of graduate unemployment was produced by the Development Policy Research Unit, School of Economics, University of Cape Town [49]. Research into private provision of intermediate ICT skills training was carried out by the Human Sciences Research Council [48]. The reports on ICT skills shortages commissioned by government departments or the ISETT SETA have, however, generally been carried out by small consulting companies and on occasion by bodies with a vested interest such as the IDC report sponsored by CISCO [47] whose figures on Networking skills seem to have been incorporated into the Scarce Skills List without questioning. ISETT SETA have collected data themselves since 2007.

It seems that requirements by government on the employment of researchers have led to some challenges: “... The prerequisite to use unemployed 'Previously Disadvantaged Individuals' made the fieldwork task extremely difficult..."[46]. In addition, the qualifications and experience of fieldworkers may be an issue in ICT-related research: “... they [fieldworkers] should be highly qualified, preferably in the ICT sector and experienced in high level research, at least on masters' level..." [46].

The data may not be easily available, particularly for large organisations: “... the information required was complex and not readily available ..." [46]. This same report goes on to note that "intelligent estimates" were provided in some cases [46: 8].

- 'Piggy-backing'

Many reports simply use secondary data, note that it is difficult to obtain accurate data, but then analyse it nonetheless [28; 50]. Very impressive reports are then based on suspect data. For example, in assessing demand:

"The main source of the analysis was the most recent reports on the topic that were provided to Accenture by the South African e-Skills Council as well as other recent information (from 2006) that was publically available." [50:8]

\subsection{Challenge 3: The political structure of the ICT landscape}

The way in which the SETA's in South Africa have been defined influences the nature of studies undertaken and some of the methodological challenges faced. International, Standard Industry Classification (ISIC) codes are assigned to each SETA and companies are considered to 'belong' to the SETA if they are assigned an ISIC code belonging to that SETA. Hence, the ISETT SETA does not comprise all organizations in the ICT Sector, "... because there are companies that have defined themselves to be in other sectors, such as professional services, despite these companies being recognized as ICT companies." [51:3]

In addition, it excludes certain other entities from being researched: “...ISETT Seta defines its sector as comprising those organisations which: Contribute towards the SDL fund; (2) Have an annual payroll exceeding R500 000.00..." [51]. It is unwise in a developing country to ignore smaller and informal entities (see previous sections).

This all impacts on data obtained during surveys: “...NonISETT companies failed to see the benefits the survey may involve for them as they belong to other SETA's..." [46].

Anomalies in SETA classification affect the conclusions reached from the data analysis: "...When defining the number of companies in the sector, there is an anomaly which interferes with the exact number of companies..." [51]. A secondary implication is that it is difficult to draw boundaries for any study, to decide what constitutes ICT and what does not, such as what constitutes an ICT company. This obviously impacts on method in various ways.

In general, governmental approaches to projects have consequences, for example, the maturity and conciseness of Requests for Proposals may impact on the scientific quality of studies: "...It is important to determine the sample size in the RFP for future research according to statistical norms. If this is not done, it could lead to distorted data ..." [46]. Governmental classifications could distort results: “... It would be advisable for future research projects to use ... a more representative company size classification to avoid distortion ..." [46]

\subsection{Challenge 4: Skills classification difficulties}

Many of the current "authoritative" studies on the ICT sector are driven or initiated by government. The skills classification system used by these studies is called the ISIC system. But this system is problematic. James et al [52] summarize this as follows: "The ISIC and NAICS classification systems have not kept pace with the fast-moving nature of the ICT industry ...". The ISIC codes were established for an industrial paradigm and are manufacturing oriented, with little definition possible in the services sector. The high level of vertical integration apparent in most ICT sectors, including South Africa, is therefore not easy to capture within the ISIC framework [52].

In the "ICT skills landscape of South Africa: A viewpoint on demand, supply and applicable international benchmarks" report, Accenture [50] states,

"Complication An accurate quantification of the overall demand is complicated by the fact that ICT skills are defined in different ways across industries and job categories Solution Through synthesizing the current research within the framework of a standardised ICT skills definition, it is possible to draw a more comprehensive picture of the actual demand situation." [50]

Consequently, problems are identified repeatedly in the classification systems used in the Skill Shortage surveys:

- ICT skills change continuously: "cross technology skills" and "interdisciplinary skills" are mentioned [32; 47; 53]. Many companies had difficulty categorizing employees according to the skills grid [46]. 
- $\quad$ Some non-ISETT companies indicated that they had no ICT personnel since their ICT work was outsourced, nevertheless outsourced services are not measured [46].

- $\quad$ The ISETT SETA 2007 study [51] focuses to a limited extent on non-ISETT companies, yet the financial and manufacturing sectors are overlooked even though they use ICT extensively and employ many ICT staff.

- It is difficult to compare the courses that the various universities offer and their contribution to reducing the skills mismatches and shortages. Research in which the frequency with which particular ICT jobs are described on Universities' web sites was counted and then compared with reported skills shortages is one attempt at this [54].

- The fact that ICT is an enabler of overall socio-economic development and is no longer restricted along strictly sectoral lines should be taken into account [55].

\subsection{Challenge 5: Higher Education MIS data}

HEMIS statistics on all courses are submitted annually by all the universities to the South African Department of Education. However, these numbers are difficult to interpret as; (1) Mergers and changes took place in the South African Higher Education landscape during the years for which numbers are available; (2) The number of students enrolled in a specific year for ICTrelated courses vs. the number qualifying cannot be directly compared, as enrolled includes students over a number of study years, while qualified relates only to students in a final year. A simple division by number years of study gives a very rough estimate; (3) The numbers do not provide any indications of the reasons for attrition; (4) The numbers do not allow a detailed analysis per programme or per module at specific universities. It is, therefore, difficult to comment on anything but broad national trends from the data. (5) The most recently released figures (at the end of 2009) are for 2006 and hence there is a lag. (6) Other factors, such as changes in the National Senior Certificate process and changes in teaching strategies at school level also make a significant difference to the educational standards of students coming into the tertiary education sector. Hence it is extremely difficult to judge how well universities are succeeding in addressing the ICT skills shortage and whether certain groups of universities and certain strategies are more successful than others.

The incomplete nature and incompatibility of this data means that reports rely all too often on detailed statistical data from only one university (see for example [50: 188-192]). This distorts the picture as South African universities are different in many respects. Universities of Technology, their students and courses are not completely representative of all universities. The 'traditional disadvantaged' universities face challenges that are very different from the 'advantaged' universities. Indeed attempts have been made by researchers to address the issues by interviewing university department heads, but the questions asked, and hence information obtained seems to be more about strategies than about the sensitive matters of supply and timeconsuming data collection regarding actual numbers of students enrolling and passing [53]. Obtaining even reasonably accurate data of this sort from the supply side can only be obtained by authorities and regulation and, as explained above, the ongoing changes in the educational landscape over the past few years, including mergers of various HEI, have made these figures almost meaningless.

\section{DISCUSSION}

In summary, the findings indicate that methodological challenges in ICT skills research relate to (1) the absence of crucial research elements; (2) the extent of data gathered; (3) the political structure of the ICT skills landscape; (4) skills classification difficulties and (5) Higher Education MIS data. These interact to create a complex research environment for the performance of meaningful research on ICT skills shortages and the complexity created should be taken into account by agencies undertaking research in this area.

There are multiple stakeholders in ICT training and education, including various competing groups such as private education and training providers versus state supported colleges and universities. In South Africa numerous state ministries are involved (Department of Education, Department of Labour, Department of Communications, Department of Public Service Administration, Department of Science and Technology) each of whom have their own interests and want to protect them. Regulatory authorities (SAQA and ISETT SETA) and advisory bodies need to be considered. The number of interested parties, each with their own priorities, many of whom are producing reports and making decisions which impact on others, inevitably adds to the confusion. This situation is risky, particularly when a very costly 'solution' is being proposed, such as the proposed implementation of the Cuban e-University model in the South African context [56].

The complexity of the problem of making reliable forecasts for supply and demand for ICT skills should not be underestimated. It requires extensive resources and the temptation to use a purely technological solution (online, voluntary surveys) is understandable, but nevertheless not sufficiently reliable. There is no intention to question the good faith of those who have undertaken the existing research or of those making decisions based on it. However, the value of purely quantitative surveys is debatable. It is clear that it is extremely time consuming to collect detailed survey data, even if an authority uses ICTs such as web-based surveys to assist in the entry and delivery of data. For example, the ISETT SETA first report noted that some companies complained that it took them two weeks to get the data together and two very large telecommunication companies simply refused. Classification problems exacerbate the problem enormously, as even if standard job titles are used, South African ICT personnel often do tasks which span several different jobs. In the case of online surveys, the real problem is that only those who can easily collect data will participate - the technology does not improve data quality, but only data delivery. Online surveys can in fact exacerbate the problem, as the feeling of accountability and responsibility that personal contact might strengthen can be lost. Ultimately the credibility of the data is severely compromised. When data is perceived to be unreliable or ambiguous it is ignored or competing agencies may duplicate, criticize, or interpret it in the way that best suits their current agenda. Evidence exists, however, that the opposite problem is even more dominant, that the quantitative data is acknowledged as unreliable but used nevertheless, with subsequent research building on the shaky foundations of the earlier reports and 
incorporating the quantitative data while adding a limited amount of qualitative data.

Foresight or prediction of trends is the work of highly specialized agencies. The nature of the ICT industry and its vulnerability to the global economic climate, as well as the fragmented nature of available information makes this a difficult task. However, just accepting the predictions offered, because the models are too difficult to be interrogated and fragmented inconsistencies make comparisons difficult, is also naïve.

A proposed way forward in order to deal with the complex problems highlighted in this paper would be to form a Research Methodologies group specifically to discuss the matters raised in this paper and that it be given the brief to suggest some guidelines and to monitor and endorse future data collection and analysis. The group should consist of professional researchers, academics interested in the matter, representatives from ICT professional bodies such as the Computer Society of South Africa and the research teams in the public services divisions tasked with collecting the data. This advisory group would need to have official standing, recognition and the support of a senior authority. In South Africa, it would need to be endorsed by the PIAC on ISAD and e-Skills Task Group.

If set up in this way, with representation by a number of practiced researchers, this group would make a considered and positive contribution. Not only should this team look for ways of making the quantitative data more reliable, by carefully selecting research subjects, researchers and methodologies, but they should also give assistance regarding collecting and analyzing qualitative data. The difficulties around skills classification and reliable statistics will remain, but such a team could assist tremendously in enabling the 'bigger picture' on ICT skills to emerge from the current fragmented landscape.

\section{CONCLUSION}

Government believes that there is consensus regarding an ICT skills shortage and is using this as grounds for potentially massive expenditure of a new ICT university, despite inconsistent evidence of the "size and shape" of the shortage to move forward on various action plans and initiatives. Other stakeholders, such as Microsoft, Neotel and Oracle have also embarked on training programmes. However, these appear to be reaching only a few suitable candidates and the sustainability of the efforts seems doubtful. Unfortunately data collected thus far by various agencies has not proved easy to interpret except in rather general ways and conclusions reached seem to be largely obvious or replication. For government to move decisively, given the fragmented picture based on current research, appears to be risky. Not only is there the possibility of fruitless expenditure if major initiatives do not correctly identify and address the real problems but these initiatives could result in skepticism regarding other, better-informed attempts in future. There appears therefore to be an urgent need for revised methodologies that are affordable, as well as credible, to research the ICT skills shortage in South Africa and for credible researchers to collaborate in doing the much-needed research. In addition, great care is needed in looking at how new forms of ICT training and education in South Africa are designed and implemented in order to effectively address the needs of both the demand side (that is organizations requiring skilled and productive ICT staff) and potential employees.

\section{REFERENCES}

[1] THE EUROPEAN E-SKILLS FORUM (2004) eskills for Europe: Towards 2010 and beyond: Synthesis report. http://ec.europa.eu/enterprise/ict/policy/doc/e-skillsforum-2004-09-fsr.pdf Accessed 14/09/2008.

[2] E-SKILLS UK About e-skills UK. http://www.eskills.com/About-us/1153 Accessed 18/11/2009.

[3] BOSCH, S.-J. (2009) Graduate vacancies set to remain level. Daily News 2009/08/26, http://news.ioljobs.co.za/article_view.php?fArticleId $=5090536$ Accessed 2010/07/30.

[4] DU TOIT, C. (2008) Wanted: 37565 ICT workers. iWeek 17 Apr 2008, http://www.iweek.co.za/ Accessed 2009/10/08.

[5] SA DOL (2007) National Scarce Skills List 2007. www.skillsportal.co.za/download_files/professional/ NSDS-Scarce_Skills_List_2007.doc Accessed 2009/06/04.

[6] NTHOIWA, J. (2009) Survey sheds light on ICT skills. ITWeb Thu, 1 October 2009, http://ww2.itweb.co.za/surveys/Skills_survey/2009/ Accessed 2010/07/30.

[7] CLOETE, R. (2008) Newly launched academy boosts SA's ICT skills Engineering News Online 30th May 2008, http://www.engineeringnews.co.za/article/newlylaunched-academy-boosts-sarsquos-ict-skills-200805-30 Accessed 2009/10/08.

[8] ANON (2009) ISETT SETA, Microsoft drive R35m skills programme. IT news Africa September 21, 2009, http://www.itnewsafrica.com/?p=3164 Accessed 2010/07/30.

[9] JOBS.CO.ZA, I. (2008) Neotel contributes to skills training. 24 April 2008, Iol Jobs.co.za Accessed 2009/10/10.

[10] CZERNOWALOW, M. e-Skills Academy faces liquidation ITWeb 22 Jan 2009 http://ww2.itweb.co.za/sections/business/ Accessed 29/10/2009.

[11] ENGELBRECHT, L. (2008) e-Skills Academy takes off IT Web 10 Mar 2008, http://www.itweb.co.za Accessed 2010/07/30.

[12] REPUBLIC OF SOUTH AFRICA (1994) Public Service Act 103 of 1994.

[13] NATIONAL COUNCIL OF PROVINCES (NCOP) (2008) Address by Naledi Pandor, MP, Minister of Education, introducing the debate on the education budget vote. http://www.search.gov.za/info/ Accessed 27/06/2008.

[14] MAKAPELA, L. (16 October 2007) Dinaledi schools making progress. 
(http://www.southafrica.info/about/education/dinaled i-161007.htm); Accessed 18/11/2009.

[15] SAQA (n.d.) SAQA Mission http://www.saqa.org.za/ Accessed 27/06/2008.

[16] FINWEEK ((2008)) Mail and Guardian 2008/02/03, http://www.mg.co.za/article/2008-02-03-report-saeducation-in-crisis-mode Accessed 2008/02/14.

[17] MAIL AND GUARDIAN (2009) Sadtu: Splitting education ministry makes sense. Mail and Guardian 2009/05/11, http://www.mg.co.za/article/2009-0511 -sadtu-splitting-education-ministry-makes-sense Accessed 2009/06/04.

[18] SOUTH AFRICAN GOVERNMENT INFORMATION Accelerated and Shared Growth Initiative for South Africa (AsgiSA). http://www.info.gov.za/asgisa Accessed 18/11/2009.

[19] IDC (2009) Middle East \& Africa Group: Aid to Recovery: The economic impact of IT, software, and the Microsoft ecosystem on the economy. IDC Economic Impact Study.

[20] IDC (2009) Aid to Recovery: The economic impact of IT, software, and the Microsoft ecosystem on the global economy.

[21] MBEKI, T. http://www.info.gov.za/speeches/2002/0202281146a 1001.htm Accessed 14/09/2008.

[22] PERRY, S. (2008) Skills shortage needs holistic view. http://www.itweb.co.za/events/ictskills/ default.asp Accessed 27 June, 2008.

[23] SCREENAFRICA.COMTUE (2009) DoC launches e-Skills Dialogue Initiative. http://www.screenafrica.com/news/training/974208.h tm Accessed 2009/06/04.

[24] DCITA (2006) Building Australian ICT skills Australian Government, Department of Communications, Information Technology and the Arts. www.escc.org/docs/Building_Australian_ICTskills.pdf Accessed 2008/02/14.

[25] E-SKILLS UK (2008) Technology counts: IT \& telecoms insights 2008. www.e-skills.com/Researchand-policy/Insights-2008/2205 Accessed 2008/02/14.

[26] SCIME, A. (2008) Globalized computing education: Europe and the United States. Computer Science Education, 18 (1), 43-64.

[27] WALSTROM, K. A., SCHAMBACH, T. P., JONES, K. T. \& CRAMPTON, W. J. (2008) Why are students not majoring in Information Systems? J of Information Systems Education, 19 (1), 4354.

[28] SA DOC (2007) Towards a strategic framework for ICT skills development in South Africa (Internal, discussion document). No e-version.
[29] ZHANG, W. (2007) Why IS: Understanding undergraduate students' intentions to choose an Information Systems major. J of Information Systems Education, 18 (4), 447-458.

[30] VAN TONDER, C. L. (2004) Organisational Change: Theory \& Practice., Pretoria, Van Schaik Publishers.

[31] BOYLE, T. A. \& STRONG, S. E. (2006) Skills requirements of ERP graduates. J of Information Systems Education, 17 (4), 403-412.

[32] GALLIVAN, M., TRUEX, D. P. \& KVASNY, L. (2002) An analysis of the changing demand patterns for Information Technology professionals. . In Proceedings SIGCPR '02, May 14-16, .Kristiansand, Norway

[33] HATZAKIS, T., LYCET, M. \& SERRANO, A. (2007) A programme management approach for ensuring curriculum coherence in IS (higher) education. European Journal of Information Systems, $16,643-657$.

[34] KIM, Y., HSU, J. \& STERN, M. (2006) An update on the IS/IT skills gap. J of Information Systems Education, 17 (4), 395-402.

[35] LOONEY, C. A. \& AKBULUT, A. Y. (2007) Combating the IS enrolment crisis: The role of effective teachers in introductory IS courses. Communications of the Association for Information Systems, 19, 781-805.

[36] GRANGER, M. J., DICK, G., JACOBSON, C. M. \& VAN SLYKE, C. (2007) Information Systems enrollments: Challenges and Strategies. $\mathrm{J}$ of Information Systems Education, 18 (3), 303-311.

[37] FROLICK, M. N., CHEN, L. \& JANZ, B. D. (2005) Supply and demand of is faculty: A longitudinal study. Communications of the Association for Information Systems, 15, 674- 695.

[38] BEYER, S. (2008) Gender differences and intragender differences amongst Management Information Systems students. $\mathrm{J}$ of Information Systems Education, 19 (3), 10.

[39] LENT, R. W., LOPEZ, A. M. J., LOPEZ, F. G. \& HB., S. (2008) Social cognitive career theory and the prediction of interests and choice goals in the computing disciplines. Journal of Vocational Behavior, 73, 52-62.

[40] PAPASTERGIOU, M. (2008) Are Computer Science and Information Technology still masculine fields? High school students' perceptions and career choices. Computers \& Education, 51 594-608.

[41] ROSENBLOOM, J. L., ASH, R. A., DUPONT, B. \& CO, L. (2008) Why are there so few women in information technology? Assessing the role of personality in career choices. Journal of Economic Psychology, 29, 543-554. 
[42] E-SKILLS INDUSTRY LEADERSHIP BOARD (2008) Policy declaration 2008: e-Skills competences: Actions towards sustainability. Accessed 29/07/2010.

[43] ESKILLS MONITOR (2009) The Demand for eskills in Europe: Estimating the Absolute number of Unfilled Vacancies for IT professionals in Europe - a first attempt. . http://www.eskills-monitor.eu/200904/the-demand-for-e-skills-in-europe-estimating-theabsolute-number-of-unfilled-vacancies-for-itprofessionals-in-europe-\%e2\%80\%93-a-firstattempt/ Accessed 18/11/2009.

[44] MITCHELL, C. (2009) ICT Industry skills Gaps and ultra fast broadband roll-out skill requirements. http://www.ict.org.nz/index.php/04112009_ict-skillsshortage-confirmed Accessed 2009/11/05.

[45] QIANG, C. Z. (2007) China's information revolution - managing the economic and social transformation. World Bank, Washington D.C.

[46] SA DTI (2005) An analysis of the ICT skills audit for the DTI and ISETT SETA. www.isett.org.za/downloads/ICT_Skills_needs.pdf Accessed 2008/02/14.

[47] VAN HEERDEN, P. (2006) Networking skills in South Africa: Will an increased shortage hinder growth? An IDC White Paper commissioned by CISCO systems. No e-version.

[48] AKOOJEE, S., ARENDS, F. \& ROODT, J. (2007) ICT skills at the intermediate level in South Africa: Insights into private provision and labour market demand. www.hsrcpress.ac.za Accessed 2008/02/14.

[49] DPRU (2006) Graduate unemployment in postapartheid South Africa: nature and possible policy responses.
http://www.smartxchange.co.za/images/Final_Gradu ate_Unemployment_Report_March2006.pdf Accessed 2010/07/30.

[50] ACCENTURE (2008) The ICT skills landscape of South Africa: A viewpoint on demand, supply and applicable international benchmarks. http://www.doc.gov.za/images/stories/meraka/accent ure\%20report.pdf Accessed 2010/07/30.

[51] ISETT-SETA (2007) Sector skills plan 2005 - 2010 2007 version 2.0 No e-version. Unpublished work.

[52] JAMES, T., ESSELAAR, P. \& MILLER, J. (2001) Towards a better understanding of the ICT sector in South Africa: problems and opportunities for strengthening the existing knowledge base. In Proceedings of the Trade and Industrial Policy 2001 Annual Forum. Misty Hills, Muldersdrift

[53] BIRCHWOOD DECLARATION (2007) Birchwood Declaration - for Tertiary Level ICT Skills Development www.cs.ru.ac.za/ICTSkills/Declaration\%20ICTSkills\%202007.pdf Accessed 2008/02/14.

[54] SA DOC (2008) ICT Skills overview: A study of ICT programmes at tertiary level (NQF level 6) at South African universities. No e-version.

[55] SAITIS (2000) South African ICT sector development framework: Summary. http://www.thedti.gov.za/saitis/studies/jobs_skills/su mmary.pdf Accessed 2/2/2008.

[56] PARLIAMENTARY MONITORING GROUP (2010) Department of Communications Strategy Plan 2010

13. http://www.pmg.org.za/report/20100519department-communications-strategic-plan-2010-13briefing Accessed 29/07/2010. 
Appendix: Table of included South African reports with a brief summary of the research approach and main issues highlighted by the examination of each report

\begin{tabular}{|c|c|c|}
\hline Report & Research approach & $\begin{array}{l}\text { Issues highlighted through examination of } \\
\text { report }\end{array}$ \\
\hline 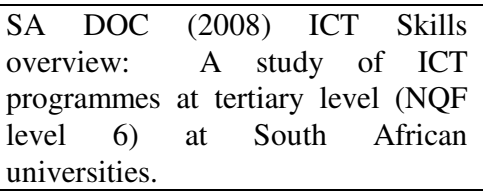 & $\begin{array}{l}\text { Both quantitative and qualitative methods } \\
\text { Data gathering: } \\
\text { - } \quad \text { published material on the Internet } \\
\text { - } \quad \text { DoE HEMIS data }\end{array}$ & $\begin{array}{l}\text { Difficulties in matching ICT programmes at } \\
\text { universities to skills shortages }\end{array}$ \\
\hline $\begin{array}{l}\text { ACCENTURE (2008) The ICT skills } \\
\text { landscape of South Africa: A viewpoint } \\
\text { on demand, supply and applicable } \\
\text { international benchmarks. }\end{array}$ & $\begin{array}{l}\text { Both quantitative and qualitative methods } \\
\text { Data gathering: } \\
\text { - literature review/ desk research } \\
\text { - } \quad \text { in-depth interviews } \\
\text { - } \quad \text { quantitative surveys }\end{array}$ & $\begin{array}{l}\text { Skills classification is an issue } \\
\text { Difficulties in accessing and collating South } \\
\text { African information on Higher Education in CIT }\end{array}$ \\
\hline $\begin{array}{l}\text { AKOOJEE, S., ARENDS, F. \& } \\
\text { ROODT, J. (2007) ICT skills at the } \\
\text { intermediate level in South Africa: } \\
\text { Insights into private provision and } \\
\text { labour market demand. }\end{array}$ & $\begin{array}{l}\text { Both quantitative and qualitative methods } \\
\text { Data gathering: } \\
\text { - existing primary government data } \\
\text { sources, } \\
\text { - literature review/ desk research } \\
\text { - } 12 \text { interviews } \\
\text { data from a South African career } \\
\text { website }\end{array}$ & Limited data gathering \\
\hline $\begin{array}{l}\text { VAN HEERDEN, P. (2006) } \\
\text { Networking skills in South Africa: Will } \\
\text { an increased shortage hinder growth? An } \\
\text { IDC White Paper commissioned by } \\
\text { CISCO systems. }\end{array}$ & $\begin{array}{l}\text { Quantitative and qualitative methods: } \\
\text { Data gathering: } \\
\text { - } 20 \text { telephonic structured interviews } \\
\text { - } \quad \text { several economic and statistical } \\
\text { indicators from ILO, EAPEP, StatsSA } \\
\text { and IDC }\end{array}$ & $\begin{array}{l}\text { Potential vested interests } \\
\text { Dynamics of changing ICT skills make classification of } \\
\text { these difficult }\end{array}$ \\
\hline $\begin{array}{l}\text { SA DOC (2007) Towards a strategic } \\
\text { framework for ICT skills development in } \\
\text { South Africa }\end{array}$ & $\begin{array}{l}\text { Quantitative methods } \\
\text { Data gathering: } \\
\text { - } \quad \text { government data sources } \\
\text { - } \quad \text { Literature review/ desk research }\end{array}$ & Piggy-backing \\
\hline $\begin{array}{l}\text { SA DOL (2007) National Scarce Skills } \\
\text { List } 2007 .\end{array}$ & $\begin{array}{l}\text { Quantitative methods } \\
\text { Data gathering: } \\
\text { - government data sources }\end{array}$ & Piggy-backing \\
\hline
\end{tabular}

